\title{
A Comprehensive Review on the Economic Status of the Global Convenience Food Industry
}

\author{
Swapan Banerjee \\ Department of Nutrition, Seacom Skills University, Kendradangal, Birbhum, West Bengal, India \\ Email: sbanerjee90@gmail.com
}

\begin{abstract}
Nowadays, people worldwide are leading to fast lifestyles due to their official work and childrens' education. The situations compel almost every earning member who does not have enough time to buy fresh vegetables and other essential food ingredients for cooking good foods both in the lunch and dinner at home. For the last two decades, mainly office goers are dependent on convenience foods called ready-to-eat foods. Disposable income, taste preferences, working stress, and psychological tenacity are the significant factors of the growing demand for fast food or ready meals among the middle-class urban population. Recent trend shows that the global convenience food market is expected to reach a $4.4 \%$ compound annual growth rate at the end of 2025. India is also supposed to be a significant contributor among other developed countries. The country is expected to reach the compound annual growth rate (CAGR) tentatively $17 \%-19 \%$ (approximately $\$ 655$ million) by 2025 . Smallscale industries (SSI) play significant roles by engaging themselves with excellent investment in the convenience food market. The increasing demand for food products is the main reason sourced from the millions of consumers worldwide. Hence, the convenience foods industry is generating better employments and higher revenues amongst other sectors.
\end{abstract}

Keywords: convenience foods; Ready-to-eat foods; Food industry; Indian food industry; lifestyles.

\section{How to Cite.}

Banerjee, S. (2021). A comprehensive review on the economic status of the global convenience food industry. International Journal of Business, Management \& Economics, 2(1), 43-52.

\section{Introduction}

As per current trends, working people worldwide are partly dependent on ready-to-eat foods, also called convenience foods. The 'no time' culture is the main reason for the dependency of the RTE foods usually observed among the working people population. According to Banerjee (2020) and Merve and Barry (2020), parents work from morning till evening. Similarly, their children are also rushing schools to private tuition throughout the day. Hence, the overall daily situations directly or indirectly pressuring the upper class or middle-class urban population to cope with ready food consumption and gross management to lifestyles.

Further, consumers are also looking for nutrition from outside cooked foods rather than home-based foods despite knowing that fruits and vegetables are the best sources of all vitamins and minerals. Here is another reason Western countries, including India, have been growing with dietary supplements due to busy lifestyles. However, as per a review study, Banerjee (2018), nutritional supplements are not always harmful if utilized for the proper purpose considering public health safety.

The objective is, first, the basic understanding of the global and Indian ready-to-eat food market. The second is to get an overview of the buyers' behaviour towards RTE foods and choices regarding preferred brand, category. Third, to get an idea of global and Indian RTE 
foods companies' economic status and management, product manufacturing, processing, and distributions. Factors influencing the market, consumers.

\section{Literature Review}

\subsection{International Perspective:}

Most of the world's population depends on ready-to-eat foods (RTE) due to short life, leading to time constraints. The global RTE food industry is projected to boost a $4.3 \%$ Compound annual growth rate (CAGR) by 2025. As per De Vries et al. (2018) study, the European market is the fastest-growing, and North America is the largest. The ready-to-eat food market is fragmented into seven major regions: Latin and North America, Eastern and Western Europe, Asia Pacific, Africa, the Middle East, and Japan. According to Quadir (2017), the APEJ market is gradually developing by the significant contributions of the most enormous and small-scale food companies because of the increasing demand of city consumers. Asia/Pacific (excluding Japan) APEJ projected and captured an $18.15 \%$ value share in 2016, and that trend is approaching to reach up to $20 \%$ by 2025. In European countries, the consumers' age group is between 18-35 years, and that group has been showing a very high demand for RTE or convenience food products. Paudyal \& Karatzas (2016) said in a study that these food products are the best alternative to regular choice because they are consumable at any time as meals or snacks. So RTE foods are among the most effective revenue generation products in the food industry and the entire global industry. However, nutrition quality must be assured by the producers at every level.

\subsection{Regulations}

The United States Food and Drug Administration (USFDA) clarified and focused on readyto-eat food and its guidelines. According to the USFDA, animal or plant-sourced foods are usually frozen, cooked, washed, processed, and instantly eaten either roasted or after heating. Therefore, Arai et al. (2002) researched the RTE as per USDA guidelines that clearly stated proper manufacturing processing and other safe processes like washing, drying, cooling, freezing, and packaging to sell over to the counter or shopping complexes.

\subsection{Multinational Network}

This market is growing faster because of the quick acceptance of middle-aged family members belonging to middle-class families. They are the consumers in response to various multinational food manufacturing companies.

\section{Research Methods}

This review study was focused on the availability, and gradual demand of ready-to-eat foods, also called convenience foods, in the current global scenario. India was isolated about the reasons of demand, procurement, supply, and nutritional aspects. The paper was designed based on extensive online searches of relevant open-access literature available in best quality and reliable databases such as Scopus, Directory of Open Access Journals (DOAJ), Google Scholar, and other government portals of food and agriculture. Keywords and phrases used for online searches: 'ready to eat food market,' 'global convenience, 'food industry,' 'India consumers,' 'Asian countries,' 'food trend,' 'lifestyles management,' and other relevant keywords. Boolean operators OR, AND, NOT were also applied during the general; keywords use for filtration. 


\section{Discussion}

\subsection{Types of Ready Eat foods or Convenience Foods available:}

- Instant Breakfast/Cereals

- Ready meals

- Instant soups and snacks.

- Meat products

- Fruits \& Vegetables

- Misc: Ice cream, Pizza, Sweet Items.

Table.1. The top global manufacturers and suppliers of RTE foods and their potentialities.

\begin{tabular}{|c|c|c|c|c|}
\hline $\begin{array}{l}\text { Name of the } \\
\text { companies }\end{array}$ & Major products & Areas of marketing & Employees ( ) & Revenue ( ) \\
\hline $\begin{array}{l}\text { McCain Foods (H.Q- } \\
\text { Canada) }\end{array}$ & Frozen potato & $\begin{array}{l}160 \text { countries, including } \\
\text { Europe Canada }\end{array}$ & 26,000 & US \$10bn \\
\hline $\begin{array}{l}\text { Birdseye under } \\
\text { trademark- Nomad } \\
\text { Foods Ltd (H.Q-UK) }\end{array}$ & Frozen foods & 17 countries & 2150 & US $\$ 2$ bn \\
\hline Nestle (Switzerland) & $\begin{array}{l}\text { Maggie, ready Poha, } \\
\text { Upma }\end{array}$ & Almost every country & $3,28,000$ & CHF 89.5bn \\
\hline $\begin{array}{l}\text { Bakkavor Foods } \\
\text { Ltd (H.Q-USA) }\end{array}$ & $\begin{array}{l}\text { Ready meals, Soups, } \\
\text { Sauces }\end{array}$ & $\begin{array}{l}\text { All states of the USA, } \\
\text { UK, China }\end{array}$ & 1000 & $\begin{array}{l}£ 1652 \\
\text { million }\end{array}$ \\
\hline $\begin{array}{l}\text { Green core Group plc } \\
\text { (Ireland) }\end{array}$ & Sugar foods & Ireland and the UK & 15,800 & $£ 145 \mathrm{Cr}$ \\
\hline General Mills (USA) & $\begin{array}{l}\text { Ready cereals, Soup, } \\
\text { Pizza, Ice cream }\end{array}$ & Entire USA, Europe & 38000 & $\begin{array}{l}\text { The US \$ } \\
15.62\end{array}$ \\
\hline $\begin{array}{l}\text { Findus Group Ltd } \\
\text { (Sweden) }\end{array}$ & $\begin{array}{l}\text { Frozen foods range, } \\
\text { Fish sticks, fish chips }\end{array}$ & $\begin{array}{l}15 \text { countries, European } \\
\text { market/exports }\end{array}$ & 4300 & US \$2bn \\
\hline IGLO (Nomad group) & Continental Europe & Europe & 2300 & US \$2bn \\
\hline $\begin{array}{l}\text { Premier Foods Group } \\
\text { Ltd (UK) }\end{array}$ & $\begin{array}{l}\text { cooking sauces, } \\
\text { custard }\end{array}$ & Europe & 4200 & $£ 824$ million \\
\hline ITC Limited (India) & $\begin{array}{l}\text { Snack foods, RTE } \\
\text { meals, juices packs, } \\
\text { dairy, and } \\
\text { confectionery. }\end{array}$ & $\begin{array}{l}\text { Indian subcontinents and } \\
\text { Gulf countries }\end{array}$ & 27279 & US $\$ 7.5 \mathrm{bn}$ \\
\hline
\end{tabular}

Data source: Global ready-to-eat RTE Food Market Size Forecast.www.businesswire.com

*All data are approximate and based on March 2019

Figure.1.showed that 14 countries in Asia are visible with citizens' average household expenses towards convenience food in proportionate to their income (\%). Some advanced countries have a significant percentage of RTE (convenience) food purchases despite producing staple foods. In a comprehensive review paper, Han et al. (2018) discussed the food packaging industry's trend based on the last few years' data. Table.1 and fig.1 concern the global markets irrespective of top food companies and ten focussed Asian countries. 


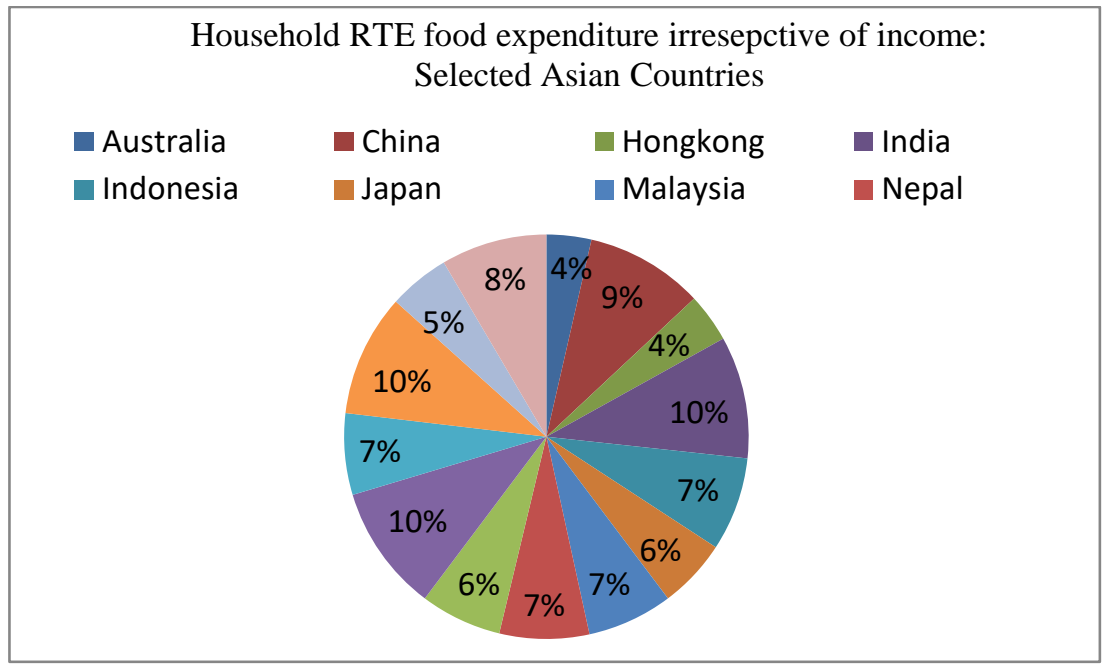

Fig.1. Asian countries (14 nos.) average convenience food purchase analysis from 2015-2019 at the household level (Data source: Future of Food Uber Eats)

\subsection{Global RTE Food Market (Parameter: packaging type)}

4.2.1 Packing - Han (2018) states that RTE foods are highly dependent on various factors, including packing. The level of graphical design, latest technological application for printing to receive emotional attraction and attachment of consumers looking for these convenience foods. The company management team assesses the psychological perception of the buyer to make products personal, transparent, easy to use. Hence, packing is very much an important marketing factor for sustainability. A good product is continuously assessed and analyzed using technology and entire packaging materials.

4.2.2. Frozen - Han (2018) also states that frozen foods and RTE should be packed scientifically as per protocol considering safety concerns. The packing box or container should be easy to fill, adequately sealed, stored in the right place. More importantly, products should be prepared with the right colouring as well as protected from spoilage. Hence the company must check that the packaging should be moistureblocking and resistant. As a result, food-grade substrates are maintained strong inside.

4.2.3. Canning - Various packing methods applied by expert commercial packers and homebased canners in the canning industry differ significantly. Industry packers use typical packing boxes and containers of various sizes, shapes, and materials following digital designs. In addition, there are types of packaging combinations such as steel, glass, aluminium, plastic cardboard, or containers. A home-based business person can elaborate his/her products whether made upon by metal or glass jars or both types of containers.

4.2.4. Chilling - Chilling is essential to make foods fresh for a long time, even in a packet or container. Proper protection of food is not only kept for a long time but also assures safety and taste. Insulated packaging presents multiple features and specifications, such as insulated box liners, temperature control pouches, environment-friendly insulated boxes, and standard ice packs. The packaging materials are alternatives to polystyrene, which is safe, environment-friendly. 


\subsection{Health perspective:}

According to Biondi (2010), people are consuming ready meals outside of their offices which are the significant causes of lifestyle diseases. High calorie, high sugar, and high trans fats from outside foods cause fatty liver diseases, obesity, diabetes, hypertension, cancer, thyroid disorder mainly hypothyroidism. Banerjee (2018) research article showed that there is a close relationship between thyroid disorders (hypothyroidism) and non-alcoholic fatty liver (NAFLD). So awareness has been continuously providing by the doctors and dietitians offline by visiting clinics and virtual through various social media. Kamala and Bhaskaram (2013) dietary guidelines showed that it is essential to follow a proper diet duly prepared at home and daily exercise at least 150 minutes a week. As per my research-based studies, Marve and Barry (2020), the best diet choice should be a vegan diet, and the best home-based practices would be yoga every day for $30 \mathrm{~min}$ and some freehand and walking. Banerjee (2020) also suggested that people avoid unwanted dietary supplements but depend on lowcalorie homemade foods. Undoubtedly, public health safety is always of utmost importance. In this article, table.2 discussed the global food market based on three parameters: Distribution Channel, Industry Value Chain Analysis, Market Analysis.

Table.2. RTE Market growth on following Parameters and Factors

\begin{tabular}{|c|c|}
\hline \multicolumn{2}{|c|}{ Global RTE Food Market (Parameter: distribution channel) Verbeke, W. (2005) } \\
\hline Distributional Channel Trends & $\begin{array}{l}\text { The current trend for channel marketing in a specific country is as per } \\
\text { the RTE food industry. }\end{array}$ \\
\hline Retail Stores & $\begin{array}{l}\text { Retailers are the closest to any consumers to sell and supply the RTE } \\
\text { foods. So they are doing local networking. }\end{array}$ \\
\hline Speciality Stores & $\begin{array}{l}\text { Speciality stores are for speciality food products. Example: } \\
\text { pastry, and ice cream as confectionary shops. }\end{array}$ \\
\hline Online Stores & Ecommerce businesses are based on lots of online stores. \\
\hline \multicolumn{2}{|l|}{ Industry Value Chain Analysis } \\
\hline Vendor Matrix & $\begin{array}{l}\text { This is a tool to evaluate vendor capacity. Third parties who can be } \\
\text { vendors to market the manufactures products }\end{array}$ \\
\hline Pricing Analysis & $\begin{array}{l}\text { One of the most exciting parts is to fixing balance pricing as per the } \\
\text { market competitors. Pricing may be variable to situations. }\end{array}$ \\
\hline Industry Impact & $\begin{array}{l}\text { The food industry is an essential industry due to daily demand. This is } \\
\text { such an industry to have always an impact on the entire industry for } \\
\text { every country. Usually, the food industry is under essential service. }\end{array}$ \\
\hline Growth Drivers & $\begin{array}{l}\text { The company management to make quarterly and yearly analyses on the } \\
\text { growth of products, annual financial assessment, share value in respect } \\
\text { of industry growth. }\end{array}$ \\
\hline Pricing Factors & $\begin{array}{l}\text { Market pricing, competition pricing, environments, climate, raw } \\
\text { materials availability, market fluctuations. }\end{array}$ \\
\hline Technological Aspects & $\begin{array}{l}\text { Uses of new machinery, tools in factories, and product testing, quality } \\
\text { control, and quality assurance to assure the quality in manufacturing } \\
\text { units. }\end{array}$ \\
\hline Regulatory Aspects & $\begin{array}{l}\text { The Government has to fix the industry guidelines that follow by all } \\
\text { companies as per the respective countries to deliver the best products for } \\
\text { achieving customer satisfaction. }\end{array}$ \\
\hline \multicolumn{2}{|l|}{ Market Analysis } \\
\hline Company Market Share & $\begin{array}{l}\text { Every food company has to analyze the share as a stock price that is } \\
\text { variables on certain factors. }\end{array}$ \\
\hline
\end{tabular}




\begin{tabular}{|c|c|}
\hline Growth Potential Analysis & $\begin{array}{l}\text { Financial assessments should measure product growth for the coming } \\
\text { quarter and the coming year to understand the existing and new } \\
\text { launching product sales or services. }\end{array}$ \\
\hline Porter's Five Forces Analysis & $\begin{array}{l}\text { This is a framework model for understanding the completion of similar } \\
\text { businesses from various economic perspectives. }\end{array}$ \\
\hline PESTEL Analysis & $\begin{array}{l}\text { Pestel analysis is for the identification of macro forces usually faced by } \\
\text { an organization. The factors are technology, environment, social, legal, } \\
\text { and economic. }\end{array}$ \\
\hline Bargaining Power of Suppliers & $\begin{array}{l}\text { Suppliers who are distributors or wholesales have the right to bargain on } \\
\text { products pricing on account of market price and its standpoints. }\end{array}$ \\
\hline Bargaining Power of Buyers & $\begin{array}{l}\text { Buyers or customers always have a right to bargain, although these are } \\
\text { pre-fixed from the manufacturer/marketer for food products. The } \\
\text { channel networking should be in the proper streamline, including for } \\
\text { retailers. At every point of channel marketing and distribution, pricing is } \\
\text { pre-fixed except local porting pricing. }\end{array}$ \\
\hline The threat of New Entrants & $\begin{array}{l}\text { The challenges for new competition apart from exiting the competition } \\
\text { in a particular market. }\end{array}$ \\
\hline Threat of Substitutes & $\begin{array}{l}\text { It may be a substitution of products or workforce, or other resources to } \\
\text { cope with the new threats. }\end{array}$ \\
\hline Intensity of Rivalry & $\begin{array}{l}\text { This is a kind of conflict facing due to market competitions and that } \\
\text { often among the exiting players. }\end{array}$ \\
\hline Strategic Outlook & $\begin{array}{l}\text { The strategic outlook is forecasting strategies based on present and } \\
\text { upcoming market situations prepared by the senior management or } \\
\text { policymakers at the government level in association with the private } \\
\text { sectors. }\end{array}$ \\
\hline
\end{tabular}

Data source: Ready to eat food RTE market study-2013-2023. www.globenewswire.com

\subsection{Indian perspective}

As per International et al. (2004), the Indian ready-to-eat or convenience food market showed at $\$ 262$ million in 2017 and is expected to rise at a CAGR of around 16\%-18\%, reaching $\$ 650$ million by 2023 .

The growth factors are depending on the following:

1. Fast lifestyles and busy schedules.

2. Lack of time for cooking at home schedule.

3. Continuous urbanization

4. The increasing level of disposable income of the middle-class population

5. Changing taste preferences

6. Easy availability of quick food as ready meals

7. Awareness/concept of the nutritional value of RTE foods

8. Tasty foods choice due to outside working cultures

9. Psychological tenacity to get rid of the boredom of work/daily lifestyles

Ka and Lugasi (2008) show that the Indian popular convenience food items are based on a single or combination of recipes made upon paneer, palak, chana masala, or rajma masala in vegetarian states. Similarly, Maharashtra and Gujarat are famous for pav bhaji, dhokla, Uttar Pradesh, Madhya Pradesh, and northern states fond of poha, upma. On the other hand, South Indians are interested in idly, dosa, sambar, rasam, curd or jeera rice, etc. Eastern states are accustomed to consuming Chinese foods, bread omelette, typical Bengali sweets, sattu 
sharbat, etc. along with plenty of rice in general. However, these are traditional or trendy snacks for state-wise or region-wise people. However, Hoque and Areful (2019) said a need for healthy, nutritious food rather than tasty conventional snacks per various cultural aspects.

Hence, there is a continuous demand and growth of ready-to-eat food products, including ready lunch meals and snacks like ready upma, poha, idly, oats, muesli, dalia. Verbeke (2005) launched the RTE concept on the markets based on innovation, sustainable packaging, and preference for frozen or dry foods products. For the last two decades, the small-scale industries are going with intensive marketing and all-out promotional activities to grow much better shortly.

In a study, Harris and Graff (2012) say that appropriate food consumption is critical to avoid any food and drug interactions or allergies caused due to hypersensitivity. Hypersensitivity may cause a skin rash, eczema, eye or teeth, or other microbial infections. That is often seen because of excess sugar, salt, preservatives, additives rich in ready-to-eat foods. The authors, Pajai and Pajai (2014), and a few more food companies' secondary data are presented in the below-mentioned table. Hence consumers' food safety awareness is vital to protect total health.

Table. 3. Indian manufacturers and suppliers of the RTE foods and their networking.

\begin{tabular}{|c|c|c|c|c|c|}
\hline Name of the companies & Major products & $\begin{array}{l}\text { Areas of } \\
\text { marketing }\end{array}$ & $\begin{array}{l}\text { Employe } \\
\text { es }(\sim) \\
\text { globally }\end{array}$ & $\begin{array}{l}\text { Revenue } \\
(\sim)\end{array}$ & Publication \\
\hline $\begin{array}{l}\text { McCain Foods (India) } \\
\text { Private Limited }\end{array}$ & $\begin{array}{l}\text { McCain French Fries, } \\
\text { McCain Smiles, } \\
\text { McCain Aloo Tikki, } \\
\text { and cheese appetizers } \\
\text { like Potato Cheese } \\
\text { Shotzand Mini } \\
\text { Samosa. }\end{array}$ & $\begin{array}{l}160 \\
\text { countries, } \\
\text { including } \\
\text { Europe } \\
\text { Canada }\end{array}$ & 26,000 & $\begin{array}{l}\text { US } \\
\$ 10 b n\end{array}$ & $\begin{array}{l}\text { Prashant } \\
\text { Parameswar } \\
\text { an } 2020 \text { and } \\
\text { Lura Wood } \\
2019 .\end{array}$ \\
\hline ITC Limited (India) & $\begin{array}{l}\text { Snack foods, RTE } \\
\text { meals, juices packs, } \\
\text { dairy, and } \\
\text { confectionery. }\end{array}$ & $\begin{array}{l}\text { Indian } \\
\text { subcontinents } \\
\text { and Gulf } \\
\text { countries }\end{array}$ & 27279 & $\begin{array}{l}\text { US } \\
\$ 7.5 \mathrm{bn}\end{array}$ & $\begin{array}{l}\text { Indian food } \\
\text { manufacture } \\
\text { rs and } \\
\text { exporters. } \\
\text { www.tofler.i } \\
\underline{\mathrm{n}}\end{array}$ \\
\hline Nestle (India) & $\begin{array}{l}\text { Maggi, milky bar, kit } \\
\text { kat, bar-one, } \\
\text { milkmaid, and Nestea }\end{array}$ & $\begin{array}{l}\text { All the states } \\
\text { in India }\end{array}$ & $3,28,000$ & $\begin{array}{l}\text { INR } \\
1,22,952 \\
\text { millions }\end{array}$ & $\begin{array}{l}\text { The key } \\
\text { financial } \\
\text { figure of } \\
\text { Nestle. } \\
\text { www.nestle.i } \\
\underline{\mathrm{n}}\end{array}$ \\
\hline MTR Foods Pvt. Ltd & $\begin{array}{l}\text { Vegetarian Soups, } \\
\text { Vegetable curries, } \\
\text { Paneer gravies, and } \\
\text { various rice items. }\end{array}$ & $\begin{array}{l}\text { India, Russia, } \\
\text { and parts of } \\
\text { Central and } \\
\text { Eastern } \\
\text { Europe }\end{array}$ & 1010 & $\begin{array}{l}\text { INR } 500 \\
\text { cr. }\end{array}$ & $\begin{array}{l}\text { Indian food } \\
\text { manufacture } \\
\text { rs and } \\
\text { exporters. } \\
\text { www.tofler.i } \\
\underline{\mathrm{n}}\end{array}$ \\
\hline $\begin{array}{l}\text { Haldiram Snacks Pvt. } \\
\text { Ltd }\end{array}$ & $\begin{array}{l}\text { Namkeen ready } \\
\text { snacks, Sweets, } \\
\text { chips, }\end{array}$ & $\begin{array}{l}\text { India and } 80 \\
\text { more } \\
\text { countries }\end{array}$ & 450 & $\begin{array}{l}\text { The US } \\
\$ 1 \text { bn. }\end{array}$ & $\begin{array}{l}\text { Audio L. } \\
\text { 2012.and } \\
\text { Indian Food } \\
\text { Industry, } \\
\text { www. } \\
\text { businesstoda } \\
\text { y. in }\end{array}$ \\
\hline
\end{tabular}




\begin{tabular}{|c|c|c|c|c|c|}
\hline $\begin{array}{l}\text { Bikanervala Foods Pvt. } \\
\text { Ltd }\end{array}$ & $\begin{array}{l}\text { Namkeen ready } \\
\text { snacks, Sweets, } \\
\text { chips, }\end{array}$ & $\begin{array}{l}\text { India and } \\
\text { other } \\
\text { countries }\end{array}$ & 216 & $\begin{array}{l}\text { INR } 500 \\
\mathrm{cr} .\end{array}$ & $\begin{array}{l}\text { Prashant } \\
\text { Parameswar } \\
\text { an } 2020\end{array}$ \\
\hline $\begin{array}{l}\text { Gits Food Products Pvt. } \\
\text { Ltd }\end{array}$ & $\begin{array}{l}\text { Ready meals, } \\
\text { Sweets-Gulab Jamun }\end{array}$ & India & 117 & $\begin{array}{l}\text { INR } 500 \\
\text { cr. }\end{array}$ & $\begin{array}{l}\text { Grubhub, } \\
2018\end{array}$ \\
\hline $\begin{array}{l}\text { Godrej Tyson Foods } \\
\text { Limited }\end{array}$ & $\begin{array}{l}\text { Poultry and ready to } \\
\text { cook }\end{array}$ & India & $500+$ & $\begin{array}{l}\text { INR } 300 \\
\text { cr. }\end{array}$ & $\begin{array}{l}\text { Kolluri et al. } \\
2021\end{array}$ \\
\hline Venky's Group & $\begin{array}{l}\text { Processed foods, } \\
\text { poultry foods }\end{array}$ & India & 1200 & $\$ 2 \mathrm{bn}$ & $\begin{array}{l}\text { Uber } \\
\text { Eats.2019 }\end{array}$ \\
\hline $\begin{array}{l}\text { Al Kabeer Exports Pvt. } \\
\text { Ltd }\end{array}$ & $\begin{array}{l}\text { Meat, processed } \\
\text { foods }\end{array}$ & $\begin{array}{l}\text { India \& } \\
\text { middle-east }\end{array}$ & $1.5 \mathrm{k}$ & $\begin{array}{l}\text { INR } 300 \\
\text { cr. }\end{array}$ & $\begin{array}{l}\text { Adekunle } \\
\text { and Filson, } \\
2020\end{array}$ \\
\hline Kohinoor Foods Ltd & $\begin{array}{l}\text { Rice, cheese, pure } \\
\text { ghee, }\end{array}$ & India abroad & 197 & $\begin{array}{l}\text { INR } 405 \\
\text { cr. }\end{array}$ & $\begin{array}{l}\text { Kohinoor } \\
\text { foods.www. } \\
\text { kohinoorfoo } \\
\text { ds.in. }\end{array}$ \\
\hline Darshan Foods Pvt. Ltd & $\begin{array}{l}\text { Bhujia, Biscuits, } \\
\text { toast, golgappa }\end{array}$ & $\begin{array}{l}\text { Indian all } \\
\text { states }\end{array}$ & 50 & $\begin{array}{l}\text { INR } 100 \\
\text { cr.< }\end{array}$ & Hoque, 2019 \\
\hline Kelloggs India & $\begin{array}{l}\text { Oats, Cornflakes, } \\
\text { others }\end{array}$ & $\begin{array}{l}\text { All across the } \\
\text { world }\end{array}$ & 31,000 & $\begin{array}{l}\text { The US } \\
\$ 13.578 \\
\text { bn }\end{array}$ & $\begin{array}{l}\text { Banerjee } \\
2019\end{array}$ \\
\hline H.J Heinz & $\begin{array}{l}\text { Canned foods, beans, } \\
\text { pulses }\end{array}$ & worldwide & 37000 & $\begin{array}{l}\text { US } \\
\$ 24.977 \\
\text { bn }\end{array}$ & $\begin{array}{l}\text { Introduction } \\
2014\end{array}$ \\
\hline $\begin{array}{l}\text { Ushodaya Enterprises } \\
\text { Pvt. Ltd }\end{array}$ & Biscuits & Indian states & 9000 & $\begin{array}{l}\text { INR } 500 \\
\mathrm{cr}\end{array}$ & $\begin{array}{l}\text { Grubhub } \\
2018\end{array}$ \\
\hline
\end{tabular}

*All data are approximate and based on 2018-2019

\section{Conclusion}

Fast lifestyles or 'no time' have changed eating behavior by changing people's cooking habits. Such a transitional city lifestyle is the cause of creating the new-generation market, the ready-to-eat (RTE), or the convenience food market. More joining of the small-scale industries and additional investments by large-scale enterprises are promising economic developments for developed and developing countries. City people, mainly office goers, are actual consumers of these ready meals and RTE or convenience foods. As a side effect, the industry must take care of its health. The healthy permitted foods ingredients must prepare the RTE foods as per government food safety guidelines. Company management must be keeping in mind that consumers are consuming these foods as they have no other way except the convenience foods. So safety is equally important with the growth of the industry.

\section{References}

Adekunle, B., Filson, G. (2020). Understanding halal food market: Resolving asymmetric information. Food ethics. 5: 13 https://doi.org/10.1007/s41055-020-00072-7.

Arai, S., Morinaga, Y., Yoshikawa, T. (2002). Recent Trends in Functional Food Science and the Industry in Japan. Biosci Biotechnol Biochem, 66(10), 2017-2029.

Audio, L. (2012). Our food: Packaging \& public health. Environmental health perspectives, 120(6), A232-A237. https://doi.org/10.1289/ehp.120-a232

Banerjee, S. (2018). A study on relationship between hypothyroidism and non-alcoholic Fatty liver disease among obese women in Kolkata intervening with diet. International Journal of Research and Development, 3(10), 43-48. 
Banerjee, S. (2019). Study on yoga intervention and diet on hypothyroidism associated with obesity among sedentary working women in West Bengal. International Journal of Yoga and Allied Sciences. 8(1), 18-23.

Banerjee, S. (2020). Role of food companies to supply nutritious foods as per buyers changing lifestyles, buying habits and the recent trends. International Journal of Innovative Research in Science, Engineering, and Technology, 9(3), 1062-1067.

Biondi, B. (2010). Thyroid and obesity: An intriguing relationship. Journal of Clinical Endocrinology and Metabolism, 95(8), 3614-3617. https://doi.org/10.1210/jc.2010-1245

De Vries, H., Mikolajczak, M., Salmon, J. M., Abecassis, J., Chaunier, L., Guessasma, S., Lourdin, D., Belhabib, S., Leroy, E., \& Trystram, G. (2018). Small-scale food process engineering-Challenges and perspectives. Innovative Food Science and Emerging Technologies. 46, 122-130.

Eats U. (on 25th May 2021). Future of food Limitation of our work. Published by Uber Eats. Source on: https://www2.deloitte.com/content/dam/Deloitte/au/Documents/Economics/deloitte-aueconomics-future-food-uber-eats-100719.pdf.

Grubhub. (2018). Grubhub releases annual "Year In Food" report detailing most population dining trends of 2018, available at: https://media.grubhub.com. It was accessed on $23^{\text {rd }}$ May 2021.

Han, J.W., Ruiz-Garcia, L., Qian, J.-P., and Yang, X. T. (2018), Food Packaging: A Comprehensive Review and Future Trends. Comprehensive Reviews in Food Science and Food Safety, 17, 860-877. https://doi.org/10.1111/1541-4337.12343

Harris, J. L., \& Graff, S. K. (2012). Protecting young people from junk food advertising: implications of psychological research for First Amendment law. American journal of public health, 102(2), 214-222. https://doi.org/10.2105/AJPH.2011.300328.

Hoque, Areful. (2019). Mouth-Watering Traditional Cuisines of India: A Study of Cultural Geography. Open Learning 2, 34-45.

Indian Food Industry (n.d). Large scale and small scale industries on RTE. www.businesstoday.in. Accessed on 18th March 2021.

International, Z., Zogby, J., Bruce, J. (2004). A study of exercise, eating habits and obesity rates among upstate new yorkers. Published online. It was accessed on 8th March 2021.

Introduction. (2014). A Comparative Study of Indigenous People between India and Bangladesh. 5(1).1927-1930.

Ka, E., and Lugasi, A. (2008). Functional food. product development, marketing, and consumer acceptance - A review, 51, 456-467.

Kamala, K., Bhaskaram, P., Bhat (2013). Rv Rt. Dietary Guidelines - A Manual. Natl Inst Nutr. 3 (1), 139.

Kohinoor Foods Products. (n.d). www.kohinoorfoods.in. It was accessed on 19th April 2021.

Kolluri, G., Tyagi, J. S., \& Sasidhar, P. V. K. (2021). Research Note: Indian poultry industry vis-à-vis coronavirus disease 2019: a situation analysis report. Poultry Science, 100(3), 100828. https://doi.org/https://doi.org/10.1016/j.psj.2020.11.011. 
Laura Wood. Global ready-to-eat RTE Food Market Size Forecast.www.businesswire.com. Published on 18th July 2019. Accessed on 7th March 2021.

Laura Wood. Ready to eat food RTE market study-2013-2023 analysis by segment distribution channel and state.www.globenewswire.com. Published on 9th January 2020. Accessed on 7th March 2021.

Merve, Y. G.M Yanar, G., \& Barry A. F. (2020). Ready-to-Eat Food Consumption Behavior. Nutrition \& Food Science International Journal, 9(5), 32-34. https://doi.org/10.19080/NFSIJ.2020.09.55577

Merve, Y.G, and Barry, A. F. (2020). Ready-to-eat food consumption behavior. Nutri Food Sci Int J, 9(5), 555775. DOI: 10.19080/NFSIJ.2019.09.555775.

Nestle India. (2021). The key financial figure of Nestle. www.nestle.in. Accessed on 20th April 2021.

Pajai, M.S, and Pajai, S. V. (2014). Journal of Pharmaceutical and Scientific Innovation Review Article. 3(2).111-113.

Paudyal, R., \& Karatzas, K. A. G. (2016). Chapter 10 - Stress adaptation of Listeria monocytogenes in acidic ready-to-eat products (P. B. T.-F. H. and T. in R.-E. F. Kotzekidou (ed.); pp. 167-182). Academic Press. https://doi.org/https://doi.org/10.1016/B978-0-12$\underline{801916-0.00010-8}$

Prashant Parameswaran (2020). A Sneak-Peak Into 2020 For Indian Snacking Industry. Available at http://www.businessworld.in/article/A-Sneak-Peak-Into-2020-For-IndianSnacking-Industry/20-12-2019-180887/. Accessed on $15^{\text {th }}$ June 21.

Quadir, S.E. (2017). An analysis of consumers' food purchasing attitudes and habits in relation to food safety an analysis of consumers' food purchasing attitudes and habits in relation to food safety. Pakistan J Nutr, 3, 241-248.

Tofler. (2021). Indian food manufacturers and exporters. www.tofler.in. Accessed on 18th April 2021.

Verbeke, W. (2005). Consumer acceptance of functional foods: Socio-demographic, cognitive and attitudinal determinants. Food Quality and Preference, 16, 45-57. https://doi.org/10.1016/j.foodqual.2004.01.001.

\section{Copyrights}

Copyright for this article is retained by the author(s), with first publication rights granted to the journal.

This is an open-access article distributed under the terms and conditions of the Creative Commons Attribution license (http://creativecommons.org/licenses/by/4.0/) 